\title{
The mobilization of aluminum into the biosphere
}

\author{
Aileen I. Pogue ${ }^{1}$ and Walter J. Lukiw ${ }^{2,3}$ * \\ ${ }^{1}$ Alchem Biotech, Toronto, ON, Canada \\ 2 Louisiana State University Neuroscience Center and Department of Ophthalmology, Louisiana State University School of Medicine, New Orleans, LA, USA \\ ${ }^{3}$ Department of Neurology, Louisiana State University Health Sciences Center, New Orleans, LA, USA \\ *Correspondence: wlukiw@Isuhsc.edu
}

Edited by:

Christopher Ariel Shaw, University of British Columbia, Canada

Reviewed by:

Lucija Tomljenovic, University of British Columbia, Canada

Keywords: aluminum, biosphere, passivation layer, Hall-Heroult-Bayer, ecosystems

Aluminum is currently the most widely used non-ferrous metal, and its extraction and purification from geological stores exceeds that of any other metal except iron $(1,2)$. In 2013, global primary aluminum production was $\sim 52$ million tons (104 billion pounds) or about 15 pounds for very person on the earth (1-4). The global outlook for aluminum demand from developing countries such as Brazil, China, India, and Indonesia is rapidly increasing, due to new applications for aluminum and aluminum alloys in infrastructural support, transportation including automobiles, aviation and aerospace applications, electrical transmission, and the generation of energy, including catalytic zeolites in the petroleum and petrochemical industries (5). Interestingly, the largest "machine" built by humankind is the domestic and international networks for the transmission of electricity. Although traditionallyused copper has a higher electrical conductivity, aluminum is only slightly less so, being lighter, more ductile, and less expensive; aluminum is now widely used for both high-voltage tower construction and the electrical transmission wires themselves (2-5). It has been estimated that within the next 10 years aluminum production will exceed that of the previous 150 years (1-3). This prolific de novo generation of aluminum combined with its highly efficient recycling means this metal is becoming increasingly present in our biosphere, defined as the sum of all ecosystems and living organisms on the earth. This short "Opinion" paper will overview and comment on the current massive mobilization of aluminum into the earth's biosphere.

\section{ALUMINUM GEOLOGY, HISTORICAL AND INDUSTRIAL PERSPECTIVES}

Bound tightly by oxygen and silicon, aluminum oxides and silicates, commonly referred to as alumina and/or aluminosilicate, exist naturally in ores generically termed bauxite. Bauxite consists mainly of the hydrated aluminum oxide $\left(\mathrm{Al}_{2} \mathrm{O}_{3} \times \mathrm{H}_{2} \mathrm{O}\right)$ minerals gibbsite, boehmite, and diaspore, and is the world's main source of raw material for the production of aluminum. Aluminum is extremely abundant; and after oxygen and silicon is the third most abundant element in the earth's crust and the most abundant metal (1-6). Bauxite ore often contains several varieties of iron oxides, mostly goethite, hematite, and the clay mineral kaolinite making them reddish in appearance; widely distributed in the tropics, rusty-red soil types called laterites are highly enriched in complex aluminum- and iron-oxides. Interestingly, as the primordial earth cooled, the lighter, lowest-density elements rose to the surface crust, and aluminum, one of the lightest metals known, currently exists in relatively easy-to-access near-the-surface deposits (7). Hence, two geophysical features make bauxite relatively easy to acquire as (i) massive bauxite deposits lie very near the earth's surface, conducive to strip mining, with little or no overburden to remove; and (ii) the aluminum content of bauxite is very high in the lithosphere, conducive to vast bauxite mining and smelting operations. It is not often appreciated that although aluminum averages $8 \%(\mathrm{w} / \mathrm{v})$ of the entire earth's crust, alumina-enriched bauxite ore deposits can often reach up to $50 \%(\mathrm{w} / \mathrm{v})$; for example, the Gove and Weipa bauxite deposits of Northern Territory and
Queensland, Australia contain $\sim 50 \%$ available alumina, and are currently among the largest, most accessible, and highest grade bauxite mines in the world $(4,6)$. Remarkably, the largest aluminum mines in Australia can extract $\sim 3,000$ tons $(6,000,000$ pounds) of bauxite per hour, and these are the largest contributors to a global aluminum production, which is currently in excess of about $\sim 6,000$ tons (12 million pounds) of $99 \%$ pure aluminum produced every hour of every day (2-5). The virtual inexhaustible supply of alumina in the earth's crust combined with the high recycling potential for aluminum (see below) guarantee to make aluminum an expanding presence and permanent fixture in our biosphere for the foreseeable future.

Alumina, aluminosilicates, and bauxite are relatively inert, naturally occurring compounds, in contrast to aluminum's extremely high reactivity in its pure elemental form (3). Aluminum was first produced experimentally in 1825 by the Danish chemist Hans Christian Oersted, and later the German, French, and Austrian chemists Friedrich Wöhler, Henri SainteClaire Deville, and Carl Joseph Bayer up-graded isolation efficiencies and purification technologies, $(7,8)$. Just $\sim 75$ years later, the inception and application of the Hall-Heroult-Bayer process, and later modifications and upgrades of this industrial technology, including implementation of the Soderberg and prebake technologies, has made aluminum mining, extraction, and purification a multibillion international industry. Global aluminum production since 1900 has increased an amazing $\sim 13,000$-fold $(3,5,7)$. In the currently used Hall-Heroult-Bayer process molten 
cryolite $\left(\mathrm{Na}_{3} \mathrm{AlF}_{6}\right)$ is used as a solvent for alumina $\left(\mathrm{Al}_{2} \mathrm{O}_{3}\right)$ and subsequent energyintensive direct current electrolysis refines the aluminum (melting point $\sim 660^{\circ} \mathrm{C}$; $\sim 1221^{\circ} \mathrm{F}$ ) to $>99 \%$ purity in a single electrochemical step (7-10). The most important chemical reaction in this operation is: $2\left(\mathrm{Al}_{2} \mathrm{O}_{3}\right)+$ electricity $->4 \mathrm{Al}^{3+}+3 \mathrm{O}_{2}$; it takes about 2 tons of alumina and $17000 \mathrm{kWh}$ of electricity to produce 1 ton of pure aluminum $(5,7)$. Interestingly, the formidable amount of energy required to produce aluminum has prompted the Russian giant metal company Rusal, now the world's largest supplier of aluminum (with a $12 \%$ global share of the aluminum market) to construct the world's first nuclear powered aluminum smelter in the Saratov region of southern Russia with a production capacity of $\sim 2.3$ million tons per year ( 525,000 pounds per hour) (10). Recycling aluminum requires only about $5 \%$ of the original production input energy, and yearly about 20 million tons (40 billion pounds) of aluminum are recycled; for example, in some Scandinavian countries yearly over $90 \%$ of aluminum is recycled (6). Remarkably, it has been estimated that approximately two-thirds of all aluminum ever produced since 1900 is still in use, partly because it is so easy to recycle it into a form that has properties virtually identical to those of "virgin" aluminum generated by primary aluminum smelting operations, $(1-5,8,9)$.

\section{ALUMINUM BONDING TO OXYGEN DONOR LIGANDS AND PASSIVATION}

The geochemistry of aluminum is relatively simple when it occurs naturally, but becomes considerably more complex when it enters our biosphere and into the biology of living organisms. The unchanging $3^{+}$valence of aluminum and small ionic radius of $0.5 \mathrm{~nm}$ make it an unusually high-charge density species with $Z^{2} / r=18$ (where $Z=$ ionic charge and $r=$ ionic radius); in fact, aluminum has by far the highest charge density of any biosphereabundant element $(7,8,11)$. Except in biological and/or environmentally acidic situations, aluminum remains tightly bound to oxygen in geological stores. For example, the metal-oxygen ( $\mathrm{Me}-\mathrm{O})$ bond dissociation energy, an indicator of how strong chemical bonds are, and how much energy is required to break them, is $122 \mathrm{kcal} / \mathrm{mol}$ for $\mathrm{Al}-\mathrm{O}$ and $98 \mathrm{kcal} / \mathrm{mol}$ for $\mathrm{Fe}-\mathrm{O}$; for comparison, the $\mathrm{Al}-\mathrm{Al}$ and $\mathrm{Fe}-\mathrm{Fe}$ dissociation energies are significantly less at 44 and $24 \mathrm{kcal} / \mathrm{mol}$, respectively (7-9). This indicates that the Al-O bond is exceedingly strong and that $\mathrm{Al}$ has a higher affinity for $\mathrm{O}$ than does $\mathrm{Fe}$ for $\mathrm{O}, \mathrm{Fe}$ for $\mathrm{Fe}$, or $\mathrm{Al}$ for $\mathrm{Al}$ (in comparison the $\mathrm{Si}-\mathrm{O}$ and $\mathrm{Si}-\mathrm{Si}$ bond energies are 191 and $78 \mathrm{kcal} / \mathrm{mol}$, respectively) (11-14). The strong Al-O bonding is responsible for the extremely high resistance of metallic aluminum to weathering and the decomposition of aluminum through contact and interaction with the earth's biosphere (see below). On the other hand, pure aluminum is extremely reactive with atmospheric oxygen, and a thin, highly protective "passivation layer" of aluminum oxide up to $\sim 4 \mathrm{~nm}$ in thickness ( 8 times the radius of the $\mathrm{Al}^{3+}$ ion) rapidly forms on exposed aluminum surfaces thus creating a physical barrier to corrosion that prevents further oxidation $(7,11,14)$. The chemistry of aluminum in geological stores is very strongly related to the capacity of aluminum to form an Al-O "passivation layer"; however, this reactivity situation changes when aluminum is exposed to the complex mixtures of oxygen donor ligands and physiological conditions normally abundant in living organisms, which populate the biosphere.

\section{ALUMINUM, THE BIOSPHERE AND BIOLOGY}

The biosphere, sometimes defined as "the self-regulating zone of all life on earth," and further divided into (i) the atmosphere that except under extraordinary dusty conditions normally contains very little free aluminum; (ii) the lithosphere that contains all raw aluminum in geologic deposits; and (iii) the hydrosphere that includes all water bodies on the earth. The estimated crustal (lithospheric) abundance of aluminum is an amazing $82.3 \mathrm{~g} / \mathrm{kg}$ while the estimated oceanic (hydrospheric) abundance of aluminum is about $2 \times 10^{-3} \mathrm{mg} / \mathrm{l}(7,9-11)$. Free $\mathrm{Al}^{3+}$ concentrations in land (lithospheric) based organisms are $\sim 10^{-11} \mathrm{~mol} / \mathrm{l}$ but may be compartmentalized at higher concentrations (15-17). There seems to be at least two possible explanations for these generally low $\mathrm{Al}^{3+}$ concentrations: either (i) the $\mathrm{Al}^{3+}$ locked in the earth's crust has been too inert and inaccessible to the biochemistry of life or (ii) biological systems have evolved to reject $\mathrm{Al}^{3+}(11-13)$. Interestingly, in the circulating physiological fluids of biological systems, including the blood, lymph, cerebrospinal fluid, and extracellular fluids whose composition, temperature, or $\mathrm{pH}$ is in constant flux between various physiological tissues and compartments, $\mathrm{Al}^{3+}$ associates with oxygen donor ligands to counter aluminum's $3^{+}$charge (11-15). In biological systems, oxygen donor ligands typically include carboxylates, organic and inorganic phosphates, nucleotides, and polynucleotides such as DNA and RNA in all of their structural forms (11, 15-19). Interestingly, unless carboxylate groups are arranged to make strong chelation possible $\mathrm{Al}^{3+}$ prefers to bind to phosphates, so the millimolar concentrations of polyphosphate in the genetic material of the nucleus may be particularly attracted to aluminum $(7,10-12,14,20) . \mathrm{Al}^{3+}$ is notorious for permanently displacing normal biological metal ions, for example, $\mathrm{Al}^{3+}$ binds almost $10^{7}$ times more strongly to ATP than does $\mathrm{Mg}^{2+}$, the normal ATP metal ion ligand, and once $\mathrm{Al}^{3+}$ acquires an energetically favorable electron-rich binding site that shields its charge it has a tendency to remain there, with high refractivity to a wide variety of chelation methods (11, 15-19). To this end, while it has often been stated that there is "no normal biological function for aluminum," its remarkable capacity to bind to DNA phosphates and aggregate chromatin and nucleic acids into highly compacted "heterochromatic" forms may have been used by evolution to shut down the expression of specific genetic information in selected cell types $(11,15-21)$. This is of note neuropathologically since only about $\sim 1$ billionth of the 15 pounds of aluminum produced yearly per person has been shown to dramatically down-regulate the expression of genes in the human brain and in doing so contribute to neurological dysfunction in a biologically detrimental disease-driving process termed "genotoxicity" (17-22). A great need currently exists to elucidate more clearly how aluminum behaves under constantly changing physiological conditions in certain compartmentalized regions of the human body, such as in the cytoplasm and nucleus, the central nervous system and cerebrovascular circulation, and how it impacts normal immune, neurological and related biological 
systems. Several excellent and extremely comprehensive reviews on the detrimental impact of aluminum on human biology have recently appeared in the scientific literature and are highly suggested reading for interested researchers of aluminum toxicity, and aluminum's current massive integration into our biosphere (23-30).

\section{CONCLUDING REMARKS}

The geological extraction, smelting, production, and purification of aluminum and its mobilization into the biosphere are increasing exponentially. There are no new materials with properties similar to aluminum currently available, and new applications for aluminum use and demand continue to rise. Approximately 1.1 billion tons $\left(2.2 \times 10^{15}\right.$ pounds $)$ of metallic aluminum have been extracted from geological deposits and exported into the biosphere since aluminum production began in earnest in 1900, and remarkably, through recycling, re-use and intrinsic longevity factors, about two-thirds of this amount is still in productive use (4-6). The continuing increase in the mobilization of aluminum into our biosphere is driven by at least six interdependent factors: (i) worldwide, the demand for aluminum is currently strong and continues to rise; (ii) there is virtually a limitless supply of the relatively inexpensive raw material bauxite in vast geologic stores to generate new aluminum; (iii) the shift from relatively inert aluminum oxide in bauxite in earthbound stores into metallic aluminum is a relatively straightforward, one-step, electro-thermal process constantly being streamlined and up-graded to higher efficiency technologies; (iv) the unique geochemical, biophysical, and chemical properties of aluminum make it relatively easy to mine, extract, purify, and recycle; (v) upwards of $90 \%$ of aluminum can be recycled back to into potentially bioavailable aluminum that is not cast back into inert geological stores; and (vi) once purified aluminum enters the biosphere, it remains there to be used in multiple products to which human beings have exposure.

Indeed, once "unlocked" from geological stores where it is relatively inactive, in many respects aluminum has become " $a r t i$ ficially and permanently integrated into the biosphere" as its primary production and bioavailability have paralleled the growth of human civilization (1-9). However, along with the ongoing mobilization of aluminum into our biosphere is an expanding list of aluminum's adverse effects on human health and welfare. Currently, the Medline database at the US National Institutes of Health (www.ncbi.nlm.nih.gov; using the keywords "aluminum" and "disease”) lists $\sim 4100$ peer-reviewed scientific papers describing multiple aspects of aluminum toxicity, and its potential contribution to a remarkably diverse number of human physiological dysfunctions and exposure-related diseases. As can be gleaned from the many research papers in this special volume of Frontiers, humankind must be wise to temper the widespread integration of this very useful metal into the biosphere with the realization that very minute amounts of aluminum in the wrong place at the wrong time in human development, physiology and neurobiology can very often be hazardous enough to generate some serious healthcare concern.

\section{ACKNOWLEDGMENTS}

This work was presented in part at the Alzheimer Association International Conference (AAIC) 2014 Annual Meeting held in Copenhagen, Denmark; thanks to Drs. S. Bhattacharjee, Y. Zhao, and D. Guillot. Research on environmental factors contributing to innate-immune/inflammatory responses in $\mathrm{AD}$ was supported by Research to Prevent Blindness (RPB) and NIH grants NEI EY006311, NIA AG18031, and NIA AG038834. Space restrictions limit the number of references and we apologize for not quoting the work of many highly accomplished aluminum researchers.

\section{REFERENCES}

1. U.S. Geological Survey, Mineral Commodity Summaries (2014). Aluminum: Prepared by E. Lee Bray. Retrieved from: http://minerals.usgs.gov/minerals/pubs/ commodity/aluminum/mcs-2014-alumi.pdf

2. IAAP; Icelandic Association of Aluminum Production (2014). About aluminium. Retrieved from: http://en.samal.is/malmurinn-frodleikur-um-al/ heimsmarkadurinn/

3. Stanford News Service (2000). Scientific Discovery: Aluminum and rust. Retrieved from: http: //news.stanford.edu/pr/00/aluminum511.html

4. Australian Aluminum Council (2010). Australian Bauxite. Retrieved from: http://aluminium.org.au/ australian-bauxite/australian-bauxite

5. The Uses of Aluminum (2014). Use in Households, Construction, Packaging, Transportation and Power Lines. Retrieved from: http://www. usesof.net/uses-of-aluminum.html

6. The International Aluminium Institute (2012). Aluminium for Future Generations. Retrieved from: http://recycling.world-aluminium.org/ home.html

7. Jefferson Lab - Science Education (2014). Its Elemental: The element aluminum. Retrieved from: http://education.jlab.org/itselemental/ ele013.html

8. Lukiw WJ. Aluminum and gene transcription in the mammalian central nervous system. In: Exley C, editor. Aluminum and Alzheimer's Disease, The Science That Describes the Link. New York, NY: Elsevier Press (2001). p. 47-68.

9. Campbell T, Kalia R, Nakano A, Vashishta P, Ogata S, Rodgers S. Dynamics of oxidation of aluminium nanoclusters using variable charge moleculardynamics simulations on parallel computers. Phys Rev Lett (1999) 82:4866. doi:10.1103/PhysRevLett. 82.4866

10. World Nuclear News (2007). Nuclear to power world's largest aluminum smelter. Retrieved from: http://www.world-nuclear-news.org/newsarticle. aspx?id $=14188 \&$ langtype $=2057$

11. Martin RB. The chemistry of aluminum as related to biology and medicine. Clin Chem (1986) 32:1797-806.

12. Kerr JA. Bond dissociation energies by kinetic methods. Chem Rev (1966) 66:465-500. doi:10. 1021/cr60243a001

13. Brown ID, Shannon RD. Empirical bondstrength-bond-length curves for oxides. Acto Crystallogr A (1973) 29:266-76. doi:10.1107/ S0567739473000689

14. Siegel S. Bond strength-bond length relationships for some metal-oxygen bonds. J Inorg Nucl Chem (1978) 40:275-83. doi:10.1016/00221902(78)80123-7

15. Walker PR, LeBlanc J, Sikorska M. Effects of aluminum and other cations on the structure of brain and liver chromatin. Biochemistry (1989) 28:3911-5. doi:10.1021/bi00435a043

16. Kruck TP, Cui JG, Percy ME, Lukiw WJ. Molecular shuttle chelation: the use of ascorbate, desferrioxamine and Feralex-G in combination to remove nuclear bound aluminum. Cell $\mathrm{Mol} \mathrm{Neu}$ robiol (2004) 24:443-59. doi:10.1023/B:CEMN. 0000022773.70722.b2

17. Lukiw WJ, Krishnan B, Wong L, Kruck TP, Bergeron C, Crapper McLachlan DR. Nuclear compartmentalization of aluminum in Alzheimer's disease (AD). Neurobiol Aging (1992) 13:115-21. doi:10.1016/0197-4580(92)90018-S

18. Bhattacharjee S, Zhao Y, Hill JM, Percy ME, Lukiw WJ. Aluminum and its potential contribution to Alzheimer's disease (AD). Front Aging Neurosci (2014) 6:62. doi:10.3389/fnagi.2014.00062

19. Lukiw WJ, McLachlan DRC. 'Neurotoxicology of aluminum' in handbook of neurotoxicology II. In: Chang L, Dyer R, editors. Effects and Mechanisms. (Vol. 4), New York, NY: Marcel Dekker (1996). p. 105-42.

20. Lukiw WJ. Evidence supporting a biological role for aluminum in chromatin compaction and epigenetics. J Inorg Biochem (2010) 104(9): 1010-2.

21. Pogue AI, Percy ME, Cui JG, Li YY, Bhattacharjee S, Hill JM, et al. Up-regulation of NF-kB-sensitive 
miRNA-125b and miRNA-146a in metal sulfatestressed human astroglial (HAG) primary cell cultures. J Inorg Biochem (2011) 105:1434-7. doi:10. 1016/j.jinorgbio.2011.05.012

22. Bhattacharjee S, Zhao Y, Hill JM, Culicchia F, Kruck TP, Percy ME, et al. Selective accumulation of aluminum in cerebral arteries in Alzheimer's disease (AD). J Inorg Biochem (2013) 126:35-7. doi:10.1016/j.jinorgbio.2013.05.007

23. Walton JR. Aluminum involvement in the progression of Alzheimer's disease. JAlzheimers Dis (2013) 35(1):7-43. doi:10.3233/JAD- 121909

24. Exley C. Human exposure to aluminium. Environ Sci Process Impacts (2013) 15:1807-16. doi:10. 1039/c3em00374d

25. Shaw CA, Tomljenovic L. Aluminum in the central nervous system (CNS): toxicity in humans and animals, vaccine adjuvants, and autoimmunity. Immunol Res (2013) 56:304-16. doi:10.1007/ s12026-013-8403-1

26. Bondy SC. Prolonged exposure to low levels of aluminum leads to changes associated with brain aging and neurodegeneration. Toxicology (2014) 315:1-7. doi:10.1016/j.tox.2013.10.008

27. Willhite CC, Karyakina NA, Yokel RA, Yenugadhati N, Wisniewski TM, Arnold IM, et al. Systematic review of potential health risks posed by pharmaceutical, occupational and consumer exposures to metallic and nanoscale aluminum, aluminum oxides, aluminum hydroxide and its soluble salts. Crit Rev Toxicol (2014) 44:1-80. doi:10. 3109/10408444.2014.934439

28. Exley C. What is the risk of aluminium as a neurotoxin? Expert Rev Neurother (2014) 14:589-91. doi:10.1586/14737175.2014.915745

29. Walton JR. Chronic aluminum intake causes Alzheimer's disease: applying Sir Austin Bradford Hill's causality criteria. J Alzheimers Dis (2014) 40:765-838. doi:10.3233/JAD- 132204

30. Shaw CA, Seneff S, Kette SD, Tomljenovic L, Oller JW Jr, Davidson RM. Aluminum-induced entropy in biological systems: implications for neurological disease. J Toxicol (2014) 2014:491316. doi:10. 1155/2014/491316
Conflict of Interest Statement: The authors declare that the research was conducted in the absence of any commercial or financial relationships that could be construed as a potential conflict of interest.

Received: 23 September 2014; paper pending published: 04 November 2014; accepted: 24 November 2014; published online: 08 December 2014.

Citation: Pogue AI and Lukiw WJ (2014) The mobilization of aluminum into the biosphere. Front. Neurol. 5:262. doi: 10.3389/fneur.2014.00262

This article was submitted to Neurodegeneration, a section of the journal Frontiers in Neurology.

Copyright (c) 2014 Pogue and Lukiw. This is an openaccess article distributed under the terms of the Creative Commons Attribution License (CC BY). The use, distribution or reproduction in other forums is permitted, provided the original author(s) or licensor are credited and that the original publication in this journal is cited, in accordance with accepted academic practice. No use, distribution or reproduction is permitted which does not comply with these terms. 